\title{
SPACE AND GROWTH: A SURVEY OF EMPIRICAL EVIDENCE AND METHODS
}

\author{
Maria ABREU1 2, Henri L.F. DE GROOT 12 \\ and Raymond J.G.M. FLORAX ${ }^{13}$
}

\begin{abstract}
This paper reviews the empirical literature on growth and convergence that has addressed the importance of spatial factors. An important distinction in this literature is the one between absolute and relative location. The literature on absolute location predominantly uses non-spatial econometric techniques, and is strongly linked to the economic growth literature. In contrast, studies on relative location tend to be weakly linked to theory, but apply relatively sophisticated econometric techniques to account for spatial effects. Most studies of the latter type are regional in nature, although there is a growing interest in extending the analysis to a cross-country setting. Both regional and cross-country studies typically make use of so-called spatial process models. Rather than modeling the impediments of space and distance directly, spatial process models start from exogenously provided information about the spatial structure. Our review shows that the usage of simple spatial autoregressive lag and error models abounds in the spatial econometrics literature. We assess the appropriateness of such models, and identify areas of potential concern. The rather weak linkage between theory and operational models, the dominance of "global" over "local" spatial association patterns, and the implicit restrictions on spatial interaction induced by many of the habitual specifications of the spatial weights matrix concurrently constitute areas where improvements can be made.
\end{abstract}

Keywords - ECONOMIC GROWTH, GEOGRAPHY, NATURAL RESOURCES, SPILLOVERS, SPATIAL ECONOMETRICS.

JEL Classification: O11, O13, O57, R11, R12.

\footnotetext{
1 Department of Spatial Economics, Free University Amsterdam (The Netherlands).

2 Tinbergen Institute (The Netherlands).

3 Department of Agricultural Economics, Purdue University (USA).

Région et Développement $n^{\circ} 21-2005$
} 


\section{INTRODUCTION}

The possibility that space is a determinant of economic growth has been considered in several empirical studies, mostly in the context of geographical variables such as latitude, climate and topology (e.g., Gallup et al., 1999). Recently, the possibility has also been explored in the spatial econometrics literature, a sub-field of econometrics dedicated to the study of spatial interaction and spatial structure (Anselin, 2001). Our aim in this article is to review the empirical literature on growth and space, starting with studies that incorporate geography into standard models of growth, and moving on to more complex models of spatial interaction. We critically assess the contribution of spatial econometrics to the study of growth in light of the broader empirical literature, and suggest directions for further research.

Previous surveys of the empirical growth literature have tended to avoid the topic of space, with some exceptions. Durlauf and Quah (1999) and De la Fuente (1997) discuss it in the context of human capital spillovers and technology diffusion. However, in these models countries differ only in their levels of human capital vis-à-vis the world average, and location plays no role in determining the extent of spillovers. It is acknowledged that space must influence the channels through which countries interact, but these channels are not modeled explicitly. Durlauf and Quah (1999) also mention a number of geography studies as part of a list of recent empirical contributions, but do not discuss them in detail.

Temple (1999) briefly discusses the possibility that disturbances in growth regressions may be correlated over space, due to omitted variables with a spatial dimension such as climate, institutions and technology. As a possible solution he suggests including country dummies as proxies for these variables. Islam (2003), focusing mainly on convergence studies, also discusses the consequences of omitting variables from the standard growth regression, and proposes using a panel data model with country fixed effects. He also considers the possibility that other parameters might vary across countries, and refers to Lee et al. (1997) in connection with this problem. These are all examples of approaches addressing spatial heterogeneity, the notion that parameters in growth models may vary across space.

Most of the research on growth in the spatial econometric literature has been carried out using regional data, possibly because spatial econometrics has traditionally been used in regional science applications, and many regional scientists are familiar with the techniques. This familiarity is also reflected in surveys of regional growth, where spatial econometrics is mentioned explicitly. Rey and Janikas (2005) review the literature on regional convergence, with a 
focus on spatial econometric techniques. However, most of their survey is dedicated to studies of regional income inequality, and the techniques discussed are mainly exploratory spatial data analysis and Markov transition matrices. Our focus in this survey is on regression techniques applied to growth processes in general, and not particularly to studies of convergence. Also on a regional note, Magrini (2004) presents an overview of the empirical literature on convergence, including studies from both the broader and the spatial econometric literatures. The author argues that regions and countries are not interchangeable concepts, and regional convergence studies should be based on different empirical methods from the ones developed to study cross-country convergence. He concludes by noting that convergence is often confined to groups of geographically contiguous regions. We discuss some of these issues in Section 3 below.

In order to structure our discussion, we make a distinction between models of absolute and relative location. Absolute location refers to the impact of being located at a particular point in space, for instance in a certain continent, climate zone or at a certain latitude. Relative location refers to the effect of being located closer or further away from other specific countries or regions. We will classify the empirical literature into several categories, according to the channel through which space affects growth, and according to whether the model is of absolute or relative location.

The distinction between models of absolute and relative location can be related to a similar classification used in spatial econometrics, that of spatial heterogeneity and spatial dependence. Spatial heterogeneity occurs when parameters in growth models vary across countries or regions depending on their location. For instance, the effects of tariffs on growth may be larger for countries located in coastal areas when compared to landlocked countries. This type of model falls into the absolute location category, since what matters is the location of a particular country in space, and not in relation to other countries.

Spatial dependence, on the other hand, occurs when the observations at one location depend on the values of observations at other locations. For example, the growth rate of a country surrounded by politically-unstable countries may be lower due to negative spillovers in the form of refugees, lower foreign direct investment and disruption to trade routes. In this case the concept of location is clearly that of relative location, since what matters is the position of a country relative to other countries.

We argue that while the spatial econometrics literature has concentrated on models of relative location (or spatial dependence), the non-spatial econometrics literature has focused on models of absolute location (or spatial heterogeneity). These two approaches are complementary. The spatial econometrics literature would benefit from considering more carefully the underlying reasons for the spatial dependence observed in the data. It may be due to the 
omission of variables with a spatial dimension such as climate, latitude and topology. Moreover, the spatial econometrics literature might gain from delving more deeply into the policy and theoretical implications of their results. On the other hand, the non-spatial econometrics literature would do well to adopt the more rigorous approach to testing, modeling and visualization of the results developed in spatial econometrics. The residuals of mainstream models should be tested for spatial dependence, since ignoring it could result in serious model misspecification.

The rest of our article is organized as follows. In Section 2, we review the treatment of space in the non-spatial econometric and the spatial econometric literatures, and discuss the distinction between models of absolute and relative location. In Section 3, we discuss several unresolved issues in the application of spatial econometrics to the study of economic growth. In Section 4, we discuss directions for further research and conclude.

\section{AN OVERVIEW OF THE LITERATURE}

This section provides a global overview of the empirical literature that has investigated the role of space in explaining variation in economic growth. In order to facilitate the discussion, we divide the literature into studies that explicitly apply spatial econometric techniques and those that do not. The former are predominantly concerned with relative location, while the latter focus on absolute location. A more detailed classification with brief descriptions and examples can be found in Table 1 .

\subsection{Space in the non-spatial econometrics literature}

The non-spatial econometrics literature has largely focused on models of absolute location, and the studies therefore (implicitly) focus on spatial heterogeneity. The notion of spatial heterogeneity that we consider here is broader than the one typically used in the spatial econometrics literature, which is tightly linked to the concept of spatial regimes 1 .

In models that apply spatial regimes, the parameters are allowed to vary across groups of countries or regions (the regimes), and oftentimes groupwise heteroscedasticity is also allowed. Our argument is that while spatial regimes is an extreme form of spatial heterogeneity, incorporating spatial variables directly into the regression also takes account of spatial heterogeneity, albeit on a more gradual and refined scale.

\footnotetext{
1 By spatial regimes we mean models in which the sample is divided into groups according to the values taken by a variable with a spatial dimension, for example North and South (according to latitude), or tropical, subtropical and temperate (according to climate zone).
} 
Table $n^{\circ}$ 1: Classification of studies

\begin{tabular}{|c|c|c|c|}
\hline \multicolumn{4}{|c|}{ ABSOLUTE LOCATION } \\
\hline Channel & Effect on growth & Measures & Examples \\
\hline Disease & $\begin{array}{c}\text { Incidence of malaria and } \\
\text { other diseases has a } \\
\text { geographical dimension. }\end{array}$ & $\begin{array}{l}\text { Climate zone, latitude, } \\
\text { average temperature. }\end{array}$ & $\begin{array}{c}\text { Bloom and Sachs } \\
\text { (1998), Gallup and } \\
\text { Sachs (2001), McArthur } \\
\text { and Sachs (2001). }\end{array}$ \\
\hline Agriculture & $\begin{array}{l}\text { Agricultural production } \\
\text { depends on soil quality, } \\
\text { topology and climate. } \\
\text { Technology developed in } \\
\text { temperate climates is not } \\
\text { suitable for tropical } \\
\text { climates. }\end{array}$ & $\begin{array}{l}\text { Climate zone, soil type, } \\
\text { average days of winter } \\
\text { frost. }\end{array}$ & $\begin{array}{c}\text { Gallup and Sachs } \\
\text { (2000), Sachs (2000), } \\
\text { Masters and McMillan } \\
\text { (2001). }\end{array}$ \\
\hline Policy & $\begin{array}{l}\text { Abundance of natural } \\
\text { resources discourages } \\
\text { industrial production and } \\
\text { results in rent-seeking. } \\
\text { Natural openness reduces } \\
\text { corruption. }\end{array}$ & $\begin{array}{l}\text { Mineral wealth, } \\
\text { landlocked dummy, } \\
\text { natural obstacles. }\end{array}$ & $\begin{array}{c}\text { Gallup et al. (1999), } \\
\text { Wei (2000). }\end{array}$ \\
\hline Institutions & $\begin{array}{l}\text { Long-run view. } \\
\text { Institutions are a result of } \\
\text { initial conditions } \\
\text { (climate, location, natural } \\
\text { resource abundance). }\end{array}$ & $\begin{array}{c}\text { Climate zone, ecological } \\
\text { diversity, latitude, } \\
\text { landlocked dummy, } \\
\text { natural obstacles, land } \\
\text { mass. }\end{array}$ & $\begin{array}{l}\text { Diamond (1997), Hall } \\
\text { and Jones (1999), } \\
\text { Acemoglu et al. (2001), } \\
\text { Rodrik et al. (2002), } \\
\text { Easterly and Levine } \\
\text { (2003). }\end{array}$ \\
\hline Trade & $\begin{array}{c}\text { Natural openness } \\
\text { encourages trade, lowers } \\
\text { corruption and allows } \\
\text { access to foreign } \\
\text { technology. }\end{array}$ & $\begin{array}{l}\text { Landlocked dummy, } \\
\text { distance to the coast, } \\
\text { navigable rivers, natural } \\
\text { obstacles, land mass. }\end{array}$ & $\begin{array}{l}\text { Sachs and Warner } \\
\text { (1997), Frankel and } \\
\text { Romer (1999). }\end{array}$ \\
\hline Spatial heterogeneity & $\begin{array}{l}\text { Parameters in growth } \\
\text { models differ across } \\
\text { economies. Countries and } \\
\text { regions are converging to } \\
\text { different steady states. }\end{array}$ & $\begin{array}{l}\text { Latitude, climate zone, } \\
\text { regional dummies. }\end{array}$ & $\begin{array}{c}\text { Barro (1991), Armstrong } \\
\text { (1995), Bivand and } \\
\text { Brunstad (2002), } \\
\text { Baumont et al. (2003), } \\
\text { Roberts (2004). }\end{array}$ \\
\hline \multicolumn{4}{|c|}{ RELATIVE LOCATION } \\
\hline Channel & Effect on growth & Measures & Examples \\
\hline Technology diffusion & $\begin{array}{l}\text { The rate of technology } \\
\text { diffusion depends on } \\
\text { distance to the } \\
\text { technology leaders. }\end{array}$ & $\begin{array}{l}\text { Geographical distance, } \\
\text { cultural distance, } \\
\text { transport costs. }\end{array}$ & $\begin{array}{c}\text { Coe and Helpman } \\
\text { (1995), Coe et al. } \\
\text { (1997), Keller (2002), } \\
\text { López-Bazo et al. } \\
\text { (2004). }\end{array}$ \\
\hline Spillovers & $\begin{array}{c}\text { Political, social and } \\
\text { economic factors in } \\
\text { neighbouring countries } \\
\text { can have an impact on } \\
\text { growth. }\end{array}$ & $\begin{array}{l}\text { Contiguity, length of the } \\
\text { border, geographical } \\
\text { distance. }\end{array}$ & $\begin{array}{l}\text { Ades and Chua (1997), } \\
\text { Easterly and Levine } \\
\text { (1998), Murdoch and } \\
\text { Sandler (2002), Lall and } \\
\text { Yilmaz (2001). }\end{array}$ \\
\hline Spatial convergence clubs & $\begin{array}{l}\text { Countries and regions are } \\
\text { converging within } \\
\text { groups. }\end{array}$ & $\begin{array}{c}\text { Contiguity, geographical } \\
\text { distance, cultural } \\
\text { distance. } \\
\end{array}$ & $\begin{array}{c}\text { Baumont et al. (2003), } \\
\text { Carrington (2003), } \\
\text { Ramajo et al. (2003). }\end{array}$ \\
\hline $\begin{array}{c}\text { Standard spatial } \\
\text { econometric analysis }\end{array}$ & $\begin{array}{l}\text { Exploratory spatial data } \\
\text { analysis, LISA, spatial } \\
\text { lag and spatial error } \\
\text { models, cross-regressive } \\
\text { term, spatial regimes. }\end{array}$ & $\begin{array}{c}\text { Contiguity, geographical } \\
\text { distance, nearest } \\
\text { neighbors, spheres of } \\
\text { influence. }\end{array}$ & $\begin{array}{l}\text { Moreno and Trehan } \\
\text { (1997), Rey and } \\
\text { Montouri (1999), Le } \\
\text { Gallo et al. (2003). }\end{array}$ \\
\hline
\end{tabular}


Although the bulk of this section will be concerned with models of absolute location, there are a few studies in the non-spatial econometrics literature that deal with relative location, notably studies of spillovers and technology diffusion. We conclude this section by discussing their significance, and how they relate to the spatial dependence models typically estimated in the spatial econometrics literature that will be reviewed in Section 2.2.

Within the literature using models of absolute location there are some studies that incorporate geographical variables directly into the analysis, so that growth is a function of variables that are invariant over time and therefore exogenous (since they precede economic growth and development). Typical examples are Hall and Jones (1996), Sachs and Warner (1997) and Lee et al. (1997), who find that latitude is a negative determinant of growth, after controlling for other social, political and economic factors.

Another part of the literature deals with the indirect effects of geography through different channels. The idea is that geographical variables can be used as instruments for other variables that have a direct effect on growth. One hypothesis linking absolute location with growth emphasizes the higher incidence of infectious diseases in the tropics. Among them, malaria is unique in that it is not a consequence of poverty, and the feasibility of eradicating it is mainly determined by climate and ecology. This allows the authors to either treat it as exogenous, or to instrument it using geographical variables. Bloom and Sachs (1998) and Gallup and Sachs (2001) find that the incidence of malaria has a negative effect on economic growth, after controlling for other variables related to policy, human capital and general health.

A related channel through which geography can have an impact on growth is agriculture. Agricultural productivity in the tropics is low because tropical soils are poor in nutrients (winter frost is essential for creating a rich topsoil) and susceptible to erosion, rainfall is variable, and pests and diseases are widespread (again due to the lack of winter frost). In addition, only a small amount of agricultural research is carried out with tropical agriculture in mind, and while machines and other equipment can be used across climate zones, new crop varieties need to be adapted to tropical climates. Gallup and Sachs (2000) find that agricultural productivity growth is substantially lower in the tropics, while Masters and McMillan (2001) show that growth increases sharply with the number of days of winter frost, particularly at low levels of frost.

The relationships found in the literature on geography and growth have led to a debate on the relative merits of geography, policy and institutions in explaining long-run growth. It has been argued that the quality of institutions and policy may be affected by geographical and climatic conditions. For example, Acemoglu et al. (2001) argue that settler mortality rates in the European colonies determined whether or not the colony became an extractive state with weak 
institutions, which persisted to this day and affect economic performance. They find that property rights, instrumented using settler mortality rates, have a positive effect on current GDP per capita. The result holds after controlling for the current disease burden, and adding other geographical and social variables. Diamond (1997) also argues that geography and natural endowments can have long-term effects on growth rates and income levels. Using his model, Hibbs and Olsson (2004) show that the variety of native plants and animals, the size of the land mass, and the orientation with respect to the Earth's axis can explain differences in current GDP per capita.

Regarding the relative merits of geography and institutions, Hall and Jones (1999), Easterly and Levine (2003) and Rodrik et al. (2002) find that geography has no effect on income per capita after controlling for its effect through institutions. Easterly and Levine (2003) also find that policy variables have no impact on development after geography and institutions have been accounted for. This finding contradicts Gallup et al. (1999) and Wei (2000) who argue that geography can affect policy by altering the trade-offs faced by the government, particularly when it comes to trade policy. On a similar note, Frankel and Romer (1999) show that trade, instrumented using geography variables, has a positive effect on income per capita.

The relationships reviewed so far correspond to a weak form of spatial heterogeneity, where variables with a spatial dimension have been included directly in the regression. A stricter concept of spatial heterogeneity is that used in spatial econometrics, where it refers to parameter instability in growth models. A simple example is the inclusion of continent dummies into a standard growth regression to control for differences in omitted variables. The idea is that countries within continents are similar to each other in terms of variables such as climate, culture and technology. Barro (1991) includes Africa and Latin America dummies as explanatory variables in a growth regression, and finds that both variables have a negative coefficient. Similarly, Armstrong (1995) finds that country dummies are jointly significant in a conditional convergence model for the regions of the European Union. Allowing the intercept to differ across countries or regions is another way of accounting for omitted variables, which would otherwise be part of the error term. For example, Islam (1995) and Caselli et al. (1996) estimate fixed effects models in order to avoid the possibility of omitted variable bias resulting from unobservable differences in technology levels across countries. Similarly, Durlauf and Johnson (1995) allow groups of countries to follow different linear growth models, depending on their initial conditions.

We now come to the studies within the non-spatial econometrics literature that focus on relative location. As we have mentioned before, they are in the minority, and mostly deal with technology diffusion and cross-country spillovers. The technology diffusion literature starts with Coe and Helpman 
(1995), who argue that productivity is a function of both domestic and foreign R\&D, with the latter spilling over through trade. Focusing on the 22 OECD countries that conduct the bulk of the world's R\&D, the authors construct measures of the domestic R\&D stock using accumulated R\&D expenditures, and measures of the foreign R\&D stock using trade-weighted measures of the R\&D stocks of each country's trade partners. In this way the authors give more weight to $R \& D$ spillovers from countries that are located relatively close in terms of bilateral trade (and indirectly in terms of physical distance, since trade is a function of physical distance). The results indicate that R\&D spillovers are substantial. In a follow up to this paper, Coe et al. (1997) extend the analysis to study R\&D spillovers from the OECD countries to a large number of lessdeveloped countries. The results indicate that R\&D spillovers from industrialized countries to less-developed countries are substantial. Keller (2002) also examines the effect of foreign $\mathrm{R} \& \mathrm{D}$ on domestic productivity, using data disaggregated by industry for a sample of OECD countries. In order to test whether technology diffusion is local or global in scope, the foreign R\&D term in the model is weighted by an exponential distance decay function. Estimation results confirm that technology spillovers are declining with physical distance. The results also indicate that sharing a common language facilitates technology diffusion, and that technology spillovers are becoming less localized over time.

Other studies of spillovers within the non-spatial econometrics literature have mostly focused on the effects of political instability in neighboring countries. Ades and Chua (1997) find that regional instability (defined as the average number of coups and revolutions in neighboring countries) has a negative effect on growth. Murdoch and Sandler (2004) find that a civil war within a distance of $800 \mathrm{~km}$ can have a negative effect on growth.

One advantage of using spatial econometrics to estimate models of technology diffusion and spillovers is that spatial relationships are summarized in a spatial weights matrix. This allows the estimation of more complex models of spatial heterogeneity and spatial dependence. However, there is also a related disadvantage, which is that the spatial weights matrix (and by extension the relationships between countries) must be exogenous and in cross-section models it should be invariant over time. This precludes using trade, foreign direct investment or measures of cultural distance as spatial weights. One possible solution could be the use of geostatistical models (discussed in Section 3), but most studies of growth using spatial econometrics have focused on physical distance as a measure of the strength of bilateral ties. Interestingly, Keller (2002) uses physical distance to capture bilateral ties in order to avoid focusing on one channel of technology diffusion. Trade, foreign direct investment, and contacts between researchers have all been shown to be a function of physical distance in the empirical literature. There may thus be an additional methodological reason for focusing on bilateral relationships measured in terms of physical distance. 


\subsection{Spatial econometrics and growth}

We now turn to the literature within spatial econometrics that has studied the impact of space on economic growth. In order to analyze the type of methods and techniques that have been used within this literature, we have compiled a list of all the spatial econometrics studies on growth (both published and unpublished) that could be found using search engines and publication databases (EconLit, SSRN, Econpapers, IDEAS). The studies are listed in chronological order in Table $n^{\circ} 2$. We have included each study only once; if a study has been published we no longer consider the original working paper.

Figure $\mathrm{n}^{\circ} 1$ shows the chronological distribution of studies. Over time, the number of published and unpublished papers increases exponentially, indicating a rising interest in applying spatial econometric techniques to the study of growth. It is also interesting to see the geographical scope of the studies. In terms of the countries or regions covered by the data, $68 \%$ of all studies use European data (at various levels of aggregation). The second largest category is comprised by studies that use country data from all continents, $11 \%$. The geographical origin of the remaining studies is the US and Canada (8\%), Latin America (6\%), Asia (5\%), and a combination of the above (2\%).

\section{Figure $n^{\circ}$ 1: Chronological distribution of studies}

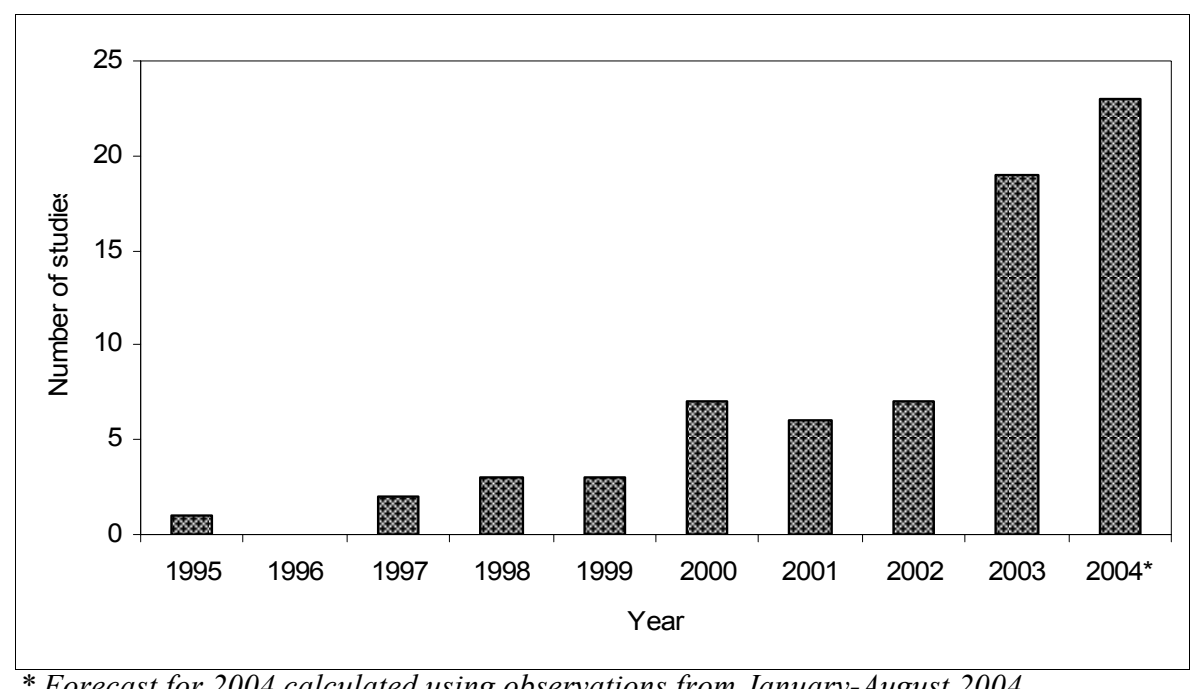

* Forecast for 2004 calculated using observations from January-August 2004.

A classification of the studies according to the channel through which location affects growth reveals that the vast majority of the studies $(63 \%)$ fall into the standard spatial econometrics category (viz., they follow standard spatial econometric procedures, and the emphasis is on methodology rather than on 
theory or policy considerations). Of these studies, $11 \%$ use spatial data analysis techniques, $6 \%$ use a spatial lag model, $29 \%$ estimate a combination of the spatial error, spatial lag, spatial cross-regressive and spatial regimes models, $11 \%$ look at Markov transition matrices, and $6 \%$ use other more unusual types of models. The distribution of the remaining studies by type of channel is almost evenly split among four categories: $8 \%$ of the studies have focused on spatial heterogeneity, $11 \%$ on technology diffusion, $10 \%$ on spatial spillovers and $8 \%$ on spatial convergence clubs. The statistics also indicate that $8 \%$ of the studies are based on models of absolute location, and $92 \%$ on models of relative location. Only $11 \%$ of all studies derive their empirical models explicitly from theory.

All of the studies based on absolute location use a spatial regimes model to investigate spatial heterogeneity. Most of them also touch on spatial dependence, either by using exploratory spatial data analysis techniques to identify clusters, testing the residuals for autocorrelation, or estimating a spatial regimes model that also allows for spatial dependence. One of the advantages of using spatial econometrics to estimate models of spatial heterogeneity resides in the possibility of testing for any remaining spatial autocorrelation, since ignoring it could result in biased coefficients. Another advantage of using spatial econometrics is that exploratory spatial data techniques can help with the identification of the spatial regimes. For example, Roberts (2004) estimates an absolute convergence model using county-level data for the United Kingdom. He finds no evidence of convergence, and a test for parameter stability across the traditional North-South divide is inconclusive. An exploratory spatial data analysis reveals a cluster of counties in the South West with low initial levels of GDP per capita. A spatial regimes model based on a structural break between the South West counties and the rest of the UK shows that while the rest of the UK is converging in terms of per-capita income, the South West is diverging.

Table $n^{\circ}$ 2: Spatial econometric studies

\begin{tabular}{|c|c|c|c|c|}
\hline Study & Channels & $\begin{array}{l}\text { Theoretical } \\
\text { background }\end{array}$ & $\begin{array}{c}\text { Geographical } \\
\text { scope }\end{array}$ & $\begin{array}{l}\text { Spatial } \\
\text { weights }\end{array}$ \\
\hline Armstrong (1995) & 5 & $\mathrm{CO}$ & B & W1 \\
\hline Ades and Chua (1997) & 3 & $\mathrm{~S}$ & A & W1 \\
\hline Moreno and Trehan (1997) & 5 & $\mathrm{~S}$ & A & W3 \\
\hline Easterly and Levine (1998) & 3 & $\mathrm{~S}$ & A & W1 \\
\hline Fingleton et al. (1998) & 2 & $\mathrm{O}$ & B & W3 \\
\hline Vayá et al. (1998) & 5 & C-P & B & W1 \\
\hline Fingleton (1999) & 5 & $\mathrm{CO}$ & B & W3 \\
\hline López-Bazo et al. (1999) & 5 & $\mathrm{NN}$ & B & W1 \\
\hline Rey and Montouri (1999) & 5 & $\mathrm{U}$ & $\mathrm{C}$ & W1 \\
\hline Aroca and Bosch (2000) & 5 & $\mathrm{U}$ & $\mathrm{D}$ & W1 \\
\hline Attfield et al. (2000) & 5 & $\mathrm{CO}$ & $\mathrm{F}$ & W3 \\
\hline Baumont et al. (2000) & 5 & $\mathrm{U}$ & B & W4 \\
\hline Cannon et al. (2000) & 1 & $\mathrm{O}$ & B & W5 \\
\hline Fingleton $(2000)^{*}$ & 2 & $\mathrm{O}$ & A & W3 \\
\hline Vayá et al. (2000)* & 2 & $\mathrm{~S}$ & B & W5 \\
\hline Ying (2000) & 5 & C-P & E & W3 \\
\hline
\end{tabular}


Bode (2001)

Fingleton (2001)*

Lall and Yilmaz (2001)

Maurseth (2001)

Niebuhr (2001)

Rey (2001)

Arbia et al. (2002)

Bivand and Brunstad (2002)

Bode (2002)

Kosfeld et al. (2002)

Paci and Pigliaru (2002)

Ramírez et al. (2002)*

Sandberg (2002)

Arbia et al. (2003)

Arbia and Paelinck (2003)*

Badinger and Tondl (2003)

Baumont et al. (2003)

Bickenbach and Bode (2003)

Bosch Mossi et al. (2003)

Carrington (2003a)*

Ertur and Le Gallo (2003)

Ertur et al. (2003)

Gustavsson et al. (2003)

Lall and Shalizi (2003)

Le Gallo and Dall'erba (2003)

Le Gallo and Ertur (2003)

Le Gallo et al. (2003)

Lundberg (2003a)

Lundberg (2003b)

Ramajo et al. (2003)

Tondl and Vuksic (2003)

Ying (2003)

Arbia and Piras (2004)

Badinger et al. (2004)

Bode (2004)

Dall'erba and Le Gallo (2004)

Egger and Pfaffermayr (2004)

Ertur et al. (2004)

Fisher and Stirböck (2004)

Kosfeld and Lauridsen (2004)

Le Gallo (2004)

López-Bazo et al. (2004)*

Murdoch and Sandler (2004)

Rey (2004)

Roberts (2004)

Verner and Tebaldi (2004)

Florax and Nijkamp (2005)

\begin{tabular}{|c|c|c|c|}
\hline 2 & $\mathrm{~S}$ & B & W4 \\
\hline 1 & $\mathrm{O}$ & B & W5 \\
\hline 3 & $\mathrm{CO}$ & C & W1 \\
\hline 2 & $\mathrm{CO}$ & B & W3 \\
\hline 5 & $\mathrm{U}$ & B & W3 \\
\hline 5 & NN & C & W1 \\
\hline 5 & $\mathrm{U}$ & B & W1 \\
\hline 1 & C-P & B & W5 \\
\hline 5 & $\mathrm{CO}$ & B & W4 \\
\hline 5 & $\mathrm{CO}$ & B & W1 \\
\hline 5 & $\mathrm{O}$ & B & W1 \\
\hline 5 & $\mathrm{~S}$ & A & W1 \\
\hline 5 & $\mathrm{CO}$ & E & W4 \\
\hline 4 & $\mathrm{O}$ & B & W1 \\
\hline 5 & $\mathrm{CC}$ & B & W1 \\
\hline 5 & $\mathrm{~S}$ & B & W3 \\
\hline 4 & CC & B & W2 \\
\hline 5 & NN & C & W1 \\
\hline 5 & $\mathrm{NN}$ & D & W1 \\
\hline 4 & $\mathrm{CC}$ & B & W5 \\
\hline 5 & NN & B & W4 \\
\hline 1 & $\mathrm{CO}$ & B & W2 \\
\hline 5 & $\mathrm{CO}$ & B & W1 \\
\hline 5 & $\mathrm{CO}$ & D & W1 \\
\hline 5 & $\mathrm{U}$ & B & W3 \\
\hline 5 & NN & B & W2 \\
\hline 5 & $\mathrm{U}$ & B & W2 \\
\hline 5 & NN & B & W5 \\
\hline 3 & $\mathrm{~S}$ & B & W1 \\
\hline 4 & $\mathrm{CC}$ & B & W3 \\
\hline 5 & $\mathrm{~S}$ & B & W1 \\
\hline 5 & C-P & E & W4 \\
\hline 5 & $\mathrm{U}$ & B & W3 \\
\hline 5 & $\mathrm{CO}$ & B & W3 \\
\hline 2 & $\mathrm{~S}$ & B & W4 \\
\hline 3 & C-P & B & W3 \\
\hline 5 & $\mathrm{~S}$ & B & W3 \\
\hline 4 & $\mathrm{CC}$ & B & W3 \\
\hline 5 & $\mathrm{CC}$ & B & W1 \\
\hline 5 & $\mathrm{CO}$ & B & W1 \\
\hline 5 & NN & B & W3 \\
\hline 2 & $\mathrm{~S}$ & B & W4 \\
\hline 3 & $\mathrm{~S}$ & A & W5 \\
\hline 5 & $\mathrm{NN}$ & $\mathrm{C}$ & W1 \\
\hline 1 & $\mathrm{CO}$ & B & W4 \\
\hline 5 & $\mathrm{U}$ & D & W1 \\
\hline 5 & $\mathrm{CO}$ & A & W3 \\
\hline
\end{tabular}

* Empirical model is derived from theory.

Channels: 1 = Spatial heterogeneity, 2 = Technology diffusion, $3=$ Spillovers, $4=$ Spatial convergence clubs, $5=$ Standard analysis; Theoretical background: $\mathrm{N}=$ None, $\mathrm{U}=$ Unconditional convergence, $\mathrm{CO}=$ Conditional convergence; $\mathrm{S}=$ Spillovers, $\mathrm{C}-\mathrm{P}=$ Core-periphery models, $\mathrm{CC}=$ Convergence clubs, $\mathrm{O}=$ Other; Geographical scope: $\mathrm{A}=$ World, $\mathrm{B}=$ Europe, $\mathrm{C}=\mathrm{US}$ and Canada, $\mathrm{D}=$ Latin America, E = Asia, F = Other; Spatial weights: W1 = Contiguity, W2 = Other binary, $\mathrm{W} 3=$ Distance, $\mathrm{W} 4=\mathrm{A}$ combination, $\mathrm{W} 5=$ Other.

Similarly, Baumont et al. (2003) use a Moran scatterplot (a diagram showing the relationship between per-capita GDP, and the distance-weighted 
average per-capita GDP in neighboring regions) to detect two clusters of regions in the European Union (North and South). A spatial regimes model indicates there is absolute convergence in the South, and absolute divergence in the North. However, spatial diagnostic tests reveal that the residuals are spatially autocorrelated, and that a spatial error model would be more appropriate. The authors therefore estimate a spatial regimes model with spatially autocorrelated error terms.

While exploratory spatial data techniques can help guide the choice of spatial regimes, there is a tendency in the spatial econometrics literature to rely solely on these methods when constructing the model. We would argue that while the non-spatial econometrics literature can gain insights from conducting these analyses, the spatial econometrics literature would benefit from linking the choice of regimes more closely to theory, for example by basing the choice of regimes on variables with a spatial dimension such as latitude and climate. This is particularly important in view of the fact that there are no tests to distinguish between spatial dependence and spatial heterogeneity ${ }^{2}$. In fact, the two can be observationally equivalent in single cross-section models (Anselin, 2001). Suppose we find a cluster of low-growth regions while conducting an exploratory spatial data analysis. The cluster could be a result of spillovers from one region to another, or it could be due to similarities between regions in the variables that affect growth (e.g., climate, technology, institutions). Note that in a panel data setting it is easier to distinguish between the two effects, since omitted variables with a spatial dimension can be picked up by region or country fixed effects. Given the difficulties involved in estimating a panel-data model using spatial econometrics (see below), it is often advisable to consider the possibility of spatial heterogeneity before proceeding to estimate a model of spatial dependence.

The remainder of this section will be devoted to models of relative location. As we have mentioned before, the spatial econometrics literature on growth has tended to focus on methodological issues, and has frequently overlooked theoretical and policy considerations. Exceptions to this rule are a number of studies on technology diffusion and spillovers. López-Bazo et al. (2004) is an example of a spatial econometric study of technology diffusion, applied to the regions of the European Union. The level of technology in each region is assumed to depend on the technology of its neighbors, which is in turn related to neighbors' stocks of human and physical capital. The empirical model is thus linked directly to theory, and the conclusions can give insights into the appropriateness of the theoretical model. The authors find that technology

2 There are unidirectional tests for spatial heterogeneity and spatial dependence. The alternative hypothesis deals with either spatial heterogeneity or spatial dependence, and in order to distinguish between the two we would need a nested model. 
diffusion is mostly restricted to within country borders, or may be significantly bounded by distance. Interestingly, the non-spatial econometric papers we discussed in the previous section arrived at similar conclusions. An example of a spatial econometric study of spillovers is Lall and Yilmaz (2001), who estimate a conditional convergence model with human capital spillovers using data for the United States. The choice of model is based both on theoretical considerations, and on the results of an exploratory spatial data analysis that suggests that human capital levels are spatially correlated. The results indicate that human capital spillovers are important in explaining income differences and convergence among the states of the US. Another example is Easterly and Levine (1998), who include a spillover effect in the form of a spatially lagged dependent variable (the average growth rate of the neighbors is included directly as an explanatory variable). While this study does not make explicit use of spatial econometrics, the method of estimation is consistent with it ${ }^{3}$. This paper is also interesting because it discusses the policy implications of the spatial multiplier effect. If one country acts to improve a variable such as human capital, all countries benefit from the spillovers. However, if all countries in the region were to simultaneously raise human capital, then the effect would be greater still, and significantly larger than what a single country can achieve on its own. This kind of policy discussion is absent from most of the spatial econometrics literature, which tends to interpret the results in an abstract manner.

An important contribution of spatial econometrics to the empirics of growth is on the topic of spatial convergence clubs. This is the notion that groups of countries share the same steady-state characteristics, and are therefore converging to the same long-run growth path. While the broader empirical growth literature has focused on the issue of club convergence among countries with similar initial values for some variables of interest, e.g., per-capita income or human capital (Durlauf and Johnson, 1995), the spatial econometrics literature has focused on the effects of location in determining club convergence.

We have classified this topic under the heading of relative location, since the notion of clubs implies that several countries must share the same spatial characteristics, but it is also related to absolute location, since these characteristics could be geographical (e.g., climate, latitude). There are several reasons to expect convergence clubs to have a spatial dimension. First, technology diffusion encourages convergence, and is also a function of relative location (physical distance, travel time). Second, the initial level of technology may have

\footnotetext{
3 Including a spatially lagged dependent variable causes a simultaneity problem, which in spatial econometrics is typically solved by estimating a reduced form of the model using Maximum Likelihood. The authors solve it by instrumenting the spatial lag with the explanatory variables of the neighbours. See also Anselin (1988) and Kelejian and Robinson (1993) for a discussion on the use of Instrumental Variables to estimate spatial lag models.
} 
a spatial dimension. For example, we have seen that institutions and technology can be a function of climate and geography. Third, we have seen that other types of spillovers tend to have a localized effect, contributing to convergence among countries or regions located close to each other.

The concept of club convergence is related to that of spatial heterogeneity, and several studies use spatial regimes to model it. One example is Dall'erba and Le Gallo (2004) who study club convergence among regions in the core and periphery of the European Union. They find convergence among the regions of the periphery but not among the regions of the core. Ramajo et al. (2003) consider the possibility that regions in the EU cohesion-fund countries (Ireland, Greece, Portugal and Spain) are converging separately from the rest of the European Union. The results show that convergence is faster among the cohesion regions. Other methods used in spatial econometrics to study club convergence include stochastic kernels (Carrington, 2003b), Markov chain modeling (Rey, 2001), and Bayesian spatial econometrics (Ertur et al., 2003)4.

We now come to the $62 \%$ of spatial econometric studies of growth that focus mainly on methodological issues. In general, these studies follow a standard procedure whereby the data is first tested for spatial autocorrelation, and the results are presented visually on a map or a Moran scatterplot. Local statistics of spatial autocorrelation can also be computed; they indicate the degree of spatial autocorrelation centered on a specific observation.

A simple model is then estimated using Ordinary Least Squares, and spatial diagnostics are computed. These indicate whether there is spatial autocorrelation in the residuals. Lagrange Multiplier tests also indicate whether a spatial lag or a spatial error model of spatial dependence is the most appropriate (following the decision rule suggested by Anselin and Florax, 1995). In a spatial lag model the growth rate of per-capita income in one country depends on the growth rate of per-capita income in its neighbors. We discuss the implications of this model in more detail in Section 3. In a spatial error model the spatial dependence is restricted to the error term. While there is sometimes a discussion on the possible causes of the observed type of spatial dependence (e.g., common shocks, climate, institutions), the empirical model is chosen on the basis of diagnostics tests carried out on the data, and not derived from a theory.

A typical example of a standard spatial econometrics study (and one of the first to apply spatial econometrics to growth) is Rey and Montouri (1999). In order to detect spatial patterns in income and growth rates across the states of the US, the authors first calculate global spatial autocorrelation statistics, and find that incomes are correlated with those of neighboring states, and that the degree

4 See Rey and Janikas (2005) for an in-depth review of these techniques and their use in spatial econometrics. 
of spatial autocorrelation varies over time (it has decreased between 1930 and 1995). Local spatial autocorrelation statistics reveal the presence of a cluster of high-income states in the Northeast Mid-Atlantic, and a cluster of low-income states in the Southeast (these results are presented visually using Moran scatterplots and maps). The authors then estimate a simple OLS regression of growth of per-capita income on initial per-capita income, and find that the residuals are spatially autocorrelated, indicating model misspecification. The tests also indicate that there is no evidence of heteroscedasticity, and that a spatial error model is preferable to a spatial lag model. The absence of heteroscedasticity leads the authors to discard spatial heterogeneity, and concentrate on spatial dependence. The estimation of a spatial error model results in lower estimates of the speed of convergence (relative to the OLS estimates; see also our discussion on interpretation in Section 3.2.1).

Recently several studies have looked at ways of extending the analysis to a panel data setting, although there are important methodological issues involved 5 . For example, Rey (2001) and Le Gallo (2004) develop exploratory spatial data techniques to study the evolution of regional income disparities over time. Badinger et al. (2004) estimate a dynamic panel-data model, using a two step procedure. The variables are first filtered to remove spatial autocorrelation, and a standard GMM estimator is then applied to the filtered data. We would argue that while this procedure allows the estimation of more complex models, it also removes some of the variation that could potentially explain differences in growth rates ${ }^{6}$. Arbia and Piras (2004) estimate a fixed-effects panel-data model that allows for spatial autocorrelation in the error term using data for the European regions, and find significant evidence of spatial clustering. The development of spatial econometric models for panel data is an area of great interest, which will undoubtedly develop further in the coming years.

\section{UNRESOLVED ISSUES}

Having discussed the advantages of applying spatial econometrics to the study of growth, we now turn to some of the weak points. A few general remarks have already been made; they concern the focus of the literature on methodological issues, and its tendency to ignore absolute location (in particular, geographical factors). We discuss a number of further issues related to the specification of spatial process models, the choice of spatial weights, and the

5 See Elhorst (2003) and Baltagi et al. (2003) for a discussion on the difficulties involved in estimating panel data models using spatial econometrics.

6 There is an additional methodological issue to be considered. The two-step procedure used in this paper implies that the coefficient of the spatial filtering and the other coefficients in the model are not determined jointly but sequentially. The properties of such a sequential estimator are not known. 
interpretation of the coefficients. We also mention some common misconceptions that are prevalent in the literature, and suggest areas where improvements can be made.

\subsection{Operationalisation}

\subsubsection{Lattice and geostatistical approaches}

There are two alternative approaches for spatial statistical analysis. The lattice or spatial process approach assumes that the unit of analysis is a discrete entity or object. Objects are linked by a spatial pattern, expressed in terms of a spatial weights matrix. Inference is based on "expanding domain" asymptotics, which is, adding more and more objects to the sample. Prediction is by extrapolation, that is, for a different set of spatial units, or for another time period (Anselin, 2002). The variance-covariance matrix is indirectly determined by the model and by the exogenous spatial weights matrix (discussed in the next section). The spatial error and spatial lag models are examples of the spatial process approach, as are most of the models used in the spatial econometrics literature within economics. The reason is that most economic models are based on discrete objects: individuals, firms, sectors, countries. A problem with this approach is that it is difficult to deal with missing observations, since every object in the model must be connected to every other via the spatial weights matrix.

In contrast, the geostatistical or direct representation approach takes as the unit of analysis data points on a continuous field or surface. Examples of a field in this sense are land prices, or average yearly rainfall. Geostatistical models do not use spatial weights matrices to summarize the spatial relationship. The variance-covariance matrix must be modeled directly, typically as a function of the distance between observations. There is no equivalent of the spatial lag model with this approach; geostatistical models apply only to the error term. One advantage of this method is that it allows "interpolation", i.e. making predictions for missing values (known as kriging).

Some studies have used the average value of proximate observations as an explanatory variable, with the degree of proximity modeled as a distance decay function (e.g., Keller, 2002). The resulting model is non-linear, but can be estimated if the data is available as a panel, or at the sectoral level7.

\footnotetext{
7 It should be noted that growth studies that include a physical distance function on the right-handside of the regression are not generally considered to be examples of the geostatistical approach unless they also model the spatial autocorrelation in the error term directly by making the variancecovariance matrix a function of distance.
} 


\subsubsection{Choice of the spatial weights matrix}

The specification of the spatial weights matrix is a major point of contention in the literature, because the choice of spatial weights can have a substantive impact on the results. The specification of a spatial weights matrix is necessary because the variance-covariance matrix (in the presence of spatial autocorrelation) contains too many parameters to be estimated using only crosssectional data8. Two approaches have been used to deal with this identification problem. In the geostatistical (direct representation) approach, the terms in the variance-covariance matrix are expressed as a direct function of the distance between the pairs of observations. In the lattice (spatial process models) approach, the variance-covariance matrix follows indirectly from the specification of the spatial process, and the choice of spatial weights matrix. One important caveat is that for identification reasons the spatial weights matrix must be exogenous to the model, i.e., it must not contain any of the exogenous or endogenous variables used in the growth regression, because otherwise the empirical model becomes highly non-linear. For this reason, most spatial weights matrices are based on distance or contiguity, since these are geographybased measures that are unambiguously exogenous (Anselin and Bera, 1998).

Another important consideration is that there must be a limit to the range of spatial dependence allowed by the spatial weights matrix. This is due to the asymptotics required to obtain consistent estimates for the parameters of the model. Intuitively, there must be a limit on the extent to which new data points change the connectedness structure for existing data points (Anselin, 2001, 2002). In practice this is not a problem for simple contiguity and distance-band contiguity matrices, since the number of neighbors does not grow with each additional observation. It may be a problem for distance-based matrices, but can be prevented by using a critical distance cut-off, above which all interactions are assumed to be negligible. Florax and Rey (1995) show that both overspecification and underspecification of the spatial weights matrix can affect the performance of spatial dependence tests and estimators of spatial process models, although the effects of overspecification are more pronounced.

In the empirical growth studies that we surveyed, a simple contiguity matrix is the most common choice (38\%), followed by distance-based weights $(29 \%)$, a combination of contiguity and distance (14\%), other non-binary types (11\%), and other binary types such as the k nearest neighbors (8\%).

Among the other non-binary types of weights there are several cases where contiguity or distance weights were modified to take into account the economic weight of the neighbors, e.g., Panama's growth rate benefits more from

\footnotetext{
8 For a sample size of $n$ observations (countries, regions), there are $n$ potentially different variance
} terms, and $n(n-1) / 2$ covariance terms (the matrix is symmetric). 
its proximity to the US than from its proximity to Peru, even if both countries fall within the same distance band. Examples are Cannon et al. (2000), Carrington (2003), Fingleton (2001) and Vayá et al. (2004).

The choice of spatial weights should ideally be based on theoretical considerations. For example, it is reasonable to expect that spillovers due to war or instability affect primarily the neighboring countries, so that a contiguity matrix (perhaps weighted by length of the common border) is appropriate. On the other hand, spillovers due to technology diffusion may have a wider reach, so a distance-based matrix is more appropriate. One might also consider travel time, trade flows and cultural distance, although these measures require careful consideration to ensure exogeneity.

A related issue concerns the choice of critical values for distance-based matrices. Whenever possible the choice should be based on theoretical considerations, such as the expected extent of the spatial spillovers, for instance. If there is a great deal of heterogeneity in the size and spatial distribution of the countries or regions under consideration, it may be difficult to choose a critical distance based on empirical considerations such as the number of unconnected observations, the number of neighbors per observation, or the value of Moran's $I$ statistic or goodness of fit of the regression. The critical distance is too often chosen by mechanical considerations such as the value of Moran's $I$.

Note also that conceptually it is possible to think of spatial weights matrices that contain parameters to be estimated within the model. However, the resulting model will be non-linear, and the parameters are not necessarily identified.

\subsection{Interpretation}

\subsubsection{Interpretation of the spatial lag coefficients}

An important issue of interpretation arises when comparing the coefficients of the spatial lag model with the corresponding coefficients of an OLS regression. Consider the following simple model:

$$
y=\alpha+\beta x+\varepsilon,
$$

where $\varepsilon$ is a random error term. The marginal effect of $x$ on $y$ is:

$$
\frac{\partial y}{\partial x}=\beta .
$$

The interpretation of $\beta$ in the spatial lag model is different. To see this consider the following spatial lag model: 


$$
y=\rho W y+\alpha+\beta x+\varepsilon,
$$

where $x$ is an explanatory variable, and $\rho$ is a parameter indicating the extent of the spatial interaction between observations with non-zero entries in $W$, the spatial weights matrix. The model can be rewritten in reduced form:

$$
y=(I-\rho W)^{-1}[\alpha+\beta x+\varepsilon] .
$$

The marginal effect of an increase in $x$ on $y$ is:

$$
\frac{\partial y}{\partial x}=\frac{\partial\left[(I-\rho W)^{-1} \beta x\right]}{\partial x}=\left[(I-\rho W)^{-1}\right] \beta,
$$

where $(1-\rho W)^{-1}$ is the spatial multiplier (see Anselin, 2002). This is equivalent to:

$$
\frac{\partial y}{\partial x^{\prime}}=(1-\rho W)^{-1} \beta .
$$

The correct interpretation of the spatial lag model and the conceptual distinction between the various effects caused by the spatial multiplier can be seen by decomposing the spatial multiplier using the formula for a sum to infinity (since $|\varrho|<1$ ):

$$
\begin{aligned}
\frac{\partial y}{\partial x^{\prime}} & =\left(I+\rho W+\rho^{2} W^{2}+\rho^{3} W^{3}+\ldots\right) \beta \\
& =I \beta+\rho W \beta+\rho^{2} W^{2} \beta+\rho^{3} W^{3} \beta \ldots
\end{aligned}
$$

The first term on the right hand side is a matrix with the direct effects on the diagonal (the effects on $y_{i}$ of a marginal change in $x_{i}$, where $i$ refers to a spatial unit), and zeros in off-diagonal positions. The second term is a matrix with zeros on the diagonal and indirect effects in the off-diagonal positions for the regions $j$, defined as the neighbors of $i$ in the spatial weights matrix. These indirect effects are spillovers of the direct effects, and both effects are local in the sense that only the regions in which there has been an exogenous shock and their neighbors are affected. The third and higher-order terms refer to spatial spillovers induced by the direct and indirect changes in the first and second terms, and can therefore be referred to as induced effects. Note that these induced effects comprise impacts on the higher-order neighbors (the neighbors of the neighbors of $i$ ) as well as feed-back effects on regions which are already experiencing direct and indirect effects. The latter has two important implications. First, this implies the spatial lag model links all the regions in the 
system, so that the spatial effects in the model are global in nature. Second, the induced effects cause the diagonal elements of the matrix $(1-\rho W)^{-1} \beta$ to be unequal to $\beta$.

The total effect of an increase in $x$ is the sum of the direct, indirect and induced effects. The direct effects are not region-specific and are represented by the estimated coefficient $\beta$. The indirect effects depend on the spatial ordering implied by the weights matrix and are typically region-specific. The induced effects are region specific as well. It is therefore incorrect to compare the coefficient $\beta$ of the spatial lag model with the coefficient $\beta$ in an OLS model, since the first represents only the direct marginal effect of an increase in $x$, while the second represents the total marginal effect.

The column sum of the elements of the spatial multiplier matrix for region $i$ represents the total effect in all regions $j$ of an exogenous shock in region $i$, while the row sum for region $i$ represents the total effect on region $i$ of a simultaneous shock in all regions $j$. Typically the former are region-specific, whereas the latter are not. Hence the magnitude of the impact of the shock depends on where it occurs.

This heterogeneity in the total effects can be exploited when constructing the model. For example, we may be interested in the impact that improving property rights in one country has on other countries in the region. The spatial econometrics literature has tended to focus on a rather technical interpretation of the results, while it could be providing interesting policy implications. ${ }^{9}$

\subsubsection{Distinction between global and local effects}

The spatial econometrics literature has tended to focus on the structural form of the spatial lag and spatial error models, in which the spatial lag terms $(W y, W x, W \varepsilon)$ appear directly on the right-hand side of the model. As we have seen in the previous section, failure to consider the model in its reduced form can lead to problems in interpreting the estimated coefficients. As with the spatial lag model, the spatial effects captured by the spatial error model are global in the sense that a shock at any location will be transmitted to all other locations following the spatial multiplier process (Anselin, 2002).

The over-reliance of the literature on the spatial error and spatial lag models has tended to obscure other models available to capture spatial effects. One possibility is the spatial cross-regressive model, which consists of including the spatial lag of one or more explanatory variables on the right hand side. An example is Lall and Yilmaz (2001), who include the spatial lag of human capital

\footnotetext{
9 See also Easterly and Levine (1998) for a non-technical discussion on the spatial multiplier, from
} a non-spatial econometrics point of view. 
to measure the effects of human capital spillovers. This approach has the advantage of confining the spatial effects to the neighbours of each observation (as defined by the spatial weights matrix), and of maintaining a strong link to theory. It often makes no sense (from a theoretical point of view) to consider a spatial lag model, which implies that growth in country $i$ is a function of all the explanatory variables in all other countries $j$ in the system. The cross-regressive model is an example of a model which is local in scope.

Another possibility is the spatial moving average model, where the error term for each region $i$ is a function of a random error term for $i$, and the average of the error term for the neighbors of $i$ :

$$
\begin{aligned}
& y=\alpha+\beta x+\varepsilon \\
& \varepsilon=\gamma W \mu+\mu,
\end{aligned}
$$

where $\gamma$ is the spatial moving average parameter. This model is also local in scope (Anselin, 2003).

We conclude this section by stressing the need for spatial econometrics to move away from a purely mechanical approach to modeling, and towards a more flexible approach that will apply a given model with local or global spillovers selectively depending on the theoretical question being considered.

\subsection{Aggregation}

\subsubsection{Ecological fallacy and modifiable areal unit problem}

Ecological fallacy is a situation that occurs when inference about an individual is made using aggregate data for a group. In general we would expect this problem to apply when individuals are clustered in groups, and the model for each individual depends on both individual and group characteristics. For example, it may not apply to macroeconomic models where all the variables that matter are at the aggregate level, but it might apply when studying sectors within countries, when the productivity of each sector depends on both sectoral and aggregate characteristics. The problem manifests itself in two ways: it becomes impossible to disentangle individual from contextual effects, and when groups contain different numbers of members the error term becomes heteroscedastic. This last issue is a common problem in spatial econometrics, since the irregular spatial distribution of countries and regions implies that each observation has a different number of neighbors. One solution is to restrict the number of neighbors to a certain number $k$, although the problem then becomes how to choose $k$ so that the model continues to make theoretical sense, since a high number would result in isolated countries having a lot of interaction with other countries, while a low number would force well-connected countries to discard many of their neighbors. 
Another solution regarding the problem of disentangling individual and contextual effects would be to use a hierarchical or multilevel model. This is an interesting possibility that has been explored using spatial econometrics, although not in connection with growth.

The modifiable areal unit problem occurs when there are several ways of drawing up boundaries for the objects under consideration. For example, regional data can often be aggregated in several ways (e.g., according to political, administrative, cultural, or labor market boundaries). The problem is that the variation in a variable of interest can be lost when changing the level of aggregation, or the boundaries of the data set. The level of aggregation should be chosen according to the theoretical model under consideration. For instance, since macroeconomic policy is made at the national level, studies of policy and growth should focus on cross-country data. Technology diffusion, on the other hand, may occur primarily within specific sectors of the economy (Keller, 2002), while EU agricultural funds are provided to regions (Ramajo et al., 2003). These considerations should be taken into account when constructing the model and defining the scope for the analysis.

\subsubsection{Choice of scale and scope of the analysis}

A related problem is the disparity in the size of spatial units that comprise the dataset used in the analysis. For example, in cross-country studies a small country like Jamaica has the same weight as China, one of the largest. Similarly the states of the US are equivalent in size and economic output to some middlesized countries, and the European NUTS classification system sometimes includes regions of different sizes together in the same category. The problem is the disaggregated nature of the data collection system, which is often done at the national level using political and administrative boundaries that differ in size across countries. Aggregating several smaller units into larger ones often makes matters worse, since it averages out the variation in the variables of interest (the modifiable areal unit problem discussed above). One solution may be to redefine the boundaries of the spatial units from scratch, using highly disaggregated data and Geographical Information Systems (see, for example, Cheshire et al., 1995, Masters and McMillan, 2001 and Kosfeld and Lauridsen, 2004).

Another aggregation problem occurs when the spillovers of interest are at a lower level of aggregation than is typically considered; for instance, technology spillovers are likely to occur across countries but within the same sector. This issue has not been explored in spatial econometrics, and it would be interesting to see an application using for example multilevel models. 


\section{CONCLUSION}

We have reviewed the spatial econometrics literature on growth, and related it to the treatment of space in the broader empirical literature. In order to structure the discussion, we have made a distinction between models of absolute and relative location, where the former refers to the impact of being located at a particular point in space, while the latter refers to the effect of being located closer or further away from other specific countries or regions. This distinction is also strongly related to a classification made in spatial econometrics between spatial heterogeneity and spatial dependence. While spatial heterogeneity is generally a function of absolute location, spatial dependence is always a function of relative location.

We have argued that while the spatial econometrics literature has concentrated on models of relative location (or spatial dependence), the nonspatial econometrics literature has focused on models of absolute location (or spatial heterogeneity). These two approaches are complementary, and the spatial econometrics literature would benefit from considering more carefully the underlying reasons for spatial dependence, while the non-spatial econometrics literature would benefit from testing for spatial dependence, since ignoring it could result in biased coefficients. Moreover, we believe that the spatial econometrics literature has unduly concentrated on methodological issues, and should link its models and results more closely to theory.

We have also considered several unresolved issues related to the spatial econometric estimation of economic growth models. Regarding the specification of spatial econometric models, we have discussed the difficulties inherent in spatial process models, and the alternative approaches that are available. Using direct representation models would dispense with some of the problems related to the construction of the spatial weights matrix. We have also discussed the tendency in spatial econometrics to focus almost entirely on the spatial lag and spatial error models, while avoiding other models that make the link to theory somewhat more explicit. The literature would benefit from exploring these models, since they provide new tools for modeling spatial effects in the context of growth. Finally, we have discussed several problems resulting from aggregation of the data used in most empirical growth analyses, and suggested possible solutions and directions for further research. 


\section{REFERENCES}

Acemoglu D., Johnson S., Robinson J.A., 2001, "The Colonial Origins of Comparative Development: An Empirical Investigation", American Economic Review, Vol. 91, p. 1369-1401.

Ades A., Chua H., 1997, "Thy Neighbor's Curse: Regional Instability and Economic Growth", Journal of Economic Growth, Vol. 2, p. 279-304.

Anselin L., 1988, Spatial Econometrics: Methods and Models, Kluwer, Dordrecht.

Anselin L., 2001, "Spatial Econometrics", in Baltagi B.H. (ed.), A Companion to Theoretical Econometrics, Blackwell Publisher, Oxford.

Anselin L., 2002, "Under the Hood. Issues in the Specification and Interpretation of Spatial Regression Models", Agricultural Economics, Vol. 27, p. 247-267.

Anselin L., 2003, "Spatial Externalities, Spatial Multipliers and Spatial Econometrics", International Regional Science Review, Vol. 26, p. 153-166.

Anselin L., Bera A., 1998, "Spatial Dependence in Linear Regression Models with an Introduction to Spatial Econometrics", in Ullah A., Giles D. (eds), Handbook of Applied Economic Statistics, Springer, Berlin.

Anselin L., Florax R.J.G.M., 1995, "Small Sample Properties of Tests for Spatial Dependence in Regression Models: Some Further Results", in Anselin L., Florax R.J.G.M. (eds), New Directions in Spatial Econometrics, p. 21-74, Springer, Berlin.

Arbia G., Basile R., Salvatore M., 2002, "Regional Convergence in Italy 19501999: A Spatial Econometric Perspective", Istituto di Studi e Analisi Economica (ISAE), Working Paper, $\mathrm{n}^{\circ}$ 29, Rome.

Arbia G., Basile R., Salvatore M., 2003, "Measuring Spatial Effects in Parametric and Non-Parametric Modelling of Regional Growth and Convergence", paper prepared for the UNU/WIDER Project Meeting on Spatial Inequality in Development, Helsinki.

Arbia G., Paelinck J., 2003, "Spatial Econometric Modelling of Regional Convergence in Continuous Time", International Regional Science Review, Vol. 26, p. 342-362.

Arbia G., Piras G., 2004, "Convergence in Per-Capita GDP across European Regions Using Panel Data Models Extended to Spatial Autocorrelation Effects", paper presented at the European Regional Science Association (ERSA) conference, Porto.

Armstrong H.W., 1995, "Convergence among Regions of the European Union, 1950-1990", Papers in Regional Science, Vol. 74, p. 143-152. 
Aroca P., Bosch Mossi M., 2000, "Crecimiento, Convergencia y Espacio en las Regiones Chilenas: 1960-1998", Estudios de Economía, Vol. 27, p. 199-224.

Attfield C., Cannon E., Demery D., Duck N., 2000, "Economic Growth and Geographic Proximity", Economics Letters, Vol. 68, p. 109-112.

Badinger H., Müller W., Tondl G., 2004, "Regional Convergence in the European Union (1985-1999): A Spatial Dynamic Panel Analysis", Regional Studies, Vol. 38, p. 241-253.

Badinger H., Tondl G., 2003, "Trade, Human Capital and Innovation: The Engines of European Regional Growth in the 1990s", in Fingleton B. (ed.), European Regional Growth, p. 215-239, Springer, Berlin.

Baltagi B., Song S.H., Koh W., 2003, "Testing Panel Data Regression Models with Spatial Error Correlation", Journal of Econometrics, Vol. 117, p. 123150.

Barro R.J., 1991, "Economic Growth in a Cross Section of Countries", Quarterly Journal of Economics, Vol. 106, p. 407-443.

Baumont C., Ertur C., Le Gallo J., 2000, "Geographic Spillover and Growth: A Spatial Econometric Analysis for the European Regions", Université de Bourgogne, LATEC, Working Paper, ${ }^{\circ}$ 2000-07, Dijon.

Baumont C., Ertur C., Le Gallo J., 2003, "Spatial Convergence Clubs and the European Regional Growth Process, 1980-1995", in Fingleton B. (ed.), European Regional Growth, p. 131-158, Springer, Berlin.

Bickenbach F., Bode E., 2003, "Evaluating the Markov Property in Studies of Economic Convergence", International Regional Science Review, Vol. 26, p. 363-392.

Bivand R., Brunstad R., 2002, "Regional Growth in Western Europe: An Empirical Exploration of Interactions with Agriculture and Agricultural Policy", Norwegian School of Economics, Department of Economics, Discussion Paper, $\mathrm{n}^{\circ}$ 01/02, Bergen.

Bloom D., Sachs J., 1998, "Geography, Demography and Economic Growth in Africa", Brookings Papers on Economic Activity, Vol. 2, p. 207-295.

Bode E., 2001, "Is Regional Innovative Activity Path-Dependent? An Empirical Analysis for Germany", Kiel Institute of World Economics, Working Paper, $\mathrm{n}^{\circ} 1058$, Kiel.

Bode E., 2002, "Regional Economic Interaction and the Role of Growth Poles in East Germany's Convergence Process", International Conference on Policy Modeling, July 4-6, Brussels. 
Bode E., 2004, "The Spatial Pattern of Localized R\&D Spillovers: An Empirical Investigation for Germany", Journal of Economic Geography, Vol. 4, p. 4364.

Bosch Mossi M., Aroca P., Fernández I., Azzoni C., 2003, "Growth Dynamics and Space in Brazil", International Regional Science Review, Vol. 26, p. 393418.

Cannon E., Demery D., Duck N., 2000, "Does Distance Matter for Economic Performance? Evidence from European Regions", University of Bristol, Department of Economics, Discussion Paper, Bristol.

Carrington A., 2003, "A Divided Europe? Regional Convergence and Neighbourhood Effects", Kyklos, Vol. 56, p. 381-394.

Carrington A., 2003, "Regional Convergence in Europe: A Stochastic Dominance Approach", University of Bradford, BCID Research Paper, Bradford.

Caselli F., Esquivel G., Lefort F., 1996, "Reopening the Convergence Debate: A New Look at Cross-Country Growth Regressions", Journal of Economic Growth, Vol. 1, p. 363-389.

Cheshire P., Furtado A., Magrini S., 1995, "Analysis of European Cities and Regions: Problems of Quantitative Comparisons", University of Reading, Discussion Paper in Urban and Regional Economics, ${ }^{\circ} 108$, Reading.

Coe D.T., Helpman E., 1995, "International R\&D Spillovers", European Economic Review, Vol. 39, p. 859-887.

Coe D.T., Helpman E., Hoffmaister A.W., 1997, "North-South R\&D Spillovers", Economic Journal, Vol. 107, p. 134-149.

Dall'erba, S., Le Gallo J., 2003, "Regional Convergence and the Impact of European Structural Funds over 1989-1999: A Spatial Econometric Analysis", University of Illinois at Urbana-Champaign, REAL Working Paper, $\mathrm{n}^{\circ}$ 03-T-14, Urbana.

De la Fuente A., 1997, "The Empirics of Growth and Convergence: A Selective Review", Journal of Economic Dynamics and Control, Vol. 21, p. 23-73.

Diamond J., 1997, Guns, Germs and Steel: The Fate of Human Societies, W.W. Norton and Co., New York.

Durlauf S.N., Quah D.T., 1999, "The New Empirics of Economic Growth", in Taylor J.B., Woodford M. (eds.), Handbook of Macroeconomics, Vol. 1A, p. 235-308, North Holland, Amsterdam.

Durlauf S., Johnson P., 1995, "Multiple Regimes and Cross-Country Growth Behaviour", Journal of Applied Econometrics, Vol. 10, p. 365-384. 
Easterly W., Levine R., 1998, "Troubles with the Neighbours: Africa's Problem, Africa's Opportunity", Journal of African Economies, Vol. 7, p. 120-142.

Easterly W., Levine R., 2003, "Tropics, Germs and Crops: How Endowments Influence Economic Development", Journal of Monetary Economics, Vol. 50, p. 3-39.

Egger P., Pfaffermayr M., 2004, "Spatial Beta and Sigma Convergence: Theoretical Foundation, Econometric Estimation and an Application to the Growth of European Regions", mimeo, University of Innsbruck, Department of Economic Theory, Economic Policy and Economic History, Innsbruck.

Elhorst P., 2003, "Specification and Estimation of Spatial Panel Data Models", International Regional Science Review, Vol. 26, p. 244-268.

Ertur C., Le Gallo J., 2003, "An Exploratory Spatial Data Analysis of European Regional Disparities, 1980-1995", in Fingleton B. (ed.), European Regional Growth, p. 55-97, Springer, Berlin.

Ertur C., Le Gallo J., Baumont C., 2004, "The European Regional Convergence Process, 1980-1995: Do Spatial Regimes and Spatial Dependence Matter?", International Regional Science Review, forthcoming.

Ertur C., Le Gallo J., LeSage J., 2003, "Local versus Global Convergence in Europe: A Bayesian Spatial Econometric Approach", University of Illinois at Urbana-Champaign, REAL Working Paper, ${ }^{\circ}$ 03-T-28, Urbana.

Fingleton B., 1999, "Estimates of Time to Economic Convergence: An Analysis of Regions of the European Union", International Regional Science Review, Vol. 22, p. 5-34.

Fingleton B., 2000, "Convergence: International Comparisons Based on a Simultaneous Equation Model with Regional Effects", International Review of Applied Economics, Vol. 14, p. 285-305.

Fingleton B., 2001, "Equilibrium and Economic Growth: Spatial Econometric Models and Simulations", Journal of Regional Science, Vol. 41, p. 117-147.

Fischer M., Stirböck C., 2004, "Regional Income Convergence in the Enlarged Europe, 1995-2000: A Spatial Econometric Perspective", Centre for European Economic Research (ZEW), Discussion Paper, ${ }^{\circ}{ }^{04}-42$, Mannheim.

Florax R.J.G.M., Nijkamp P., 2005, "Misspecification in Linear Spatial Regression Models", in Kempf-Leonard K. (ed.), Encyclopedia of Social Measurement, Academic Press, San Diego.

Florax R., Rey S., 1995, "The Impacts of Misspecified Spatial Interaction in Linear Regression Models", in Anselin L., Florax R.J.G.M. (eds), New Directions in Spatial Econometrics, p. 111-135, Springer, Berlin. 
Frankel J., Romer D., 1999, "Does Trade Cause Growth?", American Economic Review, Vol. 89, p. 379-399.

Gallup J.L., Sachs J.D., Mellinger A.D., 1999, "Geography and Economic Development", International Regional Science Review, Vol. 22, p. 179-232.

Gallup J.L., Sachs J., 2000, "Agriculture, Climate, and Technology: Why Are the Tropics Falling Behind?", American Journal of Agricultural Economics, Vol. 82, p. 731-737.

Gallup J.L., Sachs J., 2001, "The Economic Burden of Malaria", American Journal of Tropical Medicine and Hygiene, Vol. 64, p. 85-96.

Gustavsson P., Persson J., 2003, "Geography, Cost-of-Living, and Determinants to Economic Growth: A Study of the Swedish Regions, 1911-1993", Stockholm School of Economics, EIJS Working Paper, $\mathrm{n}^{\circ}$ 186, Stockholm.

Hall R.E., Jones C.I., 1996, "The Productivity of Nations", NBER Working Paper, $\mathrm{n}^{\circ}$ 5812, Cambridge, MA.

Hall R., Jones C., 1999, "Why do Some Countries Produce So Much More Output per Worker than Others?", Quarterly Journal of Economics, Vol. 114, p. 83-116.

Hibbs D., Olsson O., 2004, "Geography, Biogeography, and Why some Countries are Rich and Others are Poor", Proceedings of the National Academy of Sciences, Vol. 101, p. 3715-3720.

Islam N., 1995, "Growth Empirics: A Panel Data Approach", Quarterly Journal of Economics, Vol. 110, p. 1127-1170.

Kelejian H.H., Robinson D.P., 1993, "A Suggested Method of Estimation Method for Spatial Inderdependent Models with Autocorrelated Errors, and an Application to a County Expenditure Model", Papers in Regional Science, Vol. 72, p. 297-312.

Keller W., 2002, "Geographic Localization of International Technology Diffusion", American Economic Review, Vol. 92, p. 120-142.

Kosfeld R., Eckey H.F., Dreger C., 2002, "Regional Convergence in Unified Germany: A Spatial Econometric Perspective", University of Kassel, Department of Economics, Working Paper, $\mathrm{n}^{\circ}$ 39/02, Kassel.

Kosfeld R., Lauridsen J., 2004, "Dynamic Spatial Modelling of Regional Convergence Processes", Hamburg Institute of International Economics, HWWA Discussion Paper, $\mathrm{n}^{\circ} 261$, Hamburg.

Lall S., Shalizi Z., 2003, "Location and Growth in the Brazilian Northeast", Journal of Regional Science, Vol. 43, p. 663-681. 
Lall S., Yilmaz S., 2001, "Regional Economic Convergence: Do Policy Instruments Make a Difference?", Annals of Regional Science, Vol. 35, p. 153-166.

Le Gallo J., 2004, "Space-Time Analysis of GDP Disparities among European Regions: a Markov Chains Approach", International Regional Science Review, Vol. 27, p. 138-163.

Le Gallo J., Dall'erba S., 2003, "Spatial Econometric Analysis of the Evolution of the European Convergence Process, 1980-1999", Washington University, Economics Working Paper Archive at WUSTL, $\mathrm{n}^{\circ}$ 0311001, Washington DC.

Le Gallo J., Ertur C., 2003, "Exploratory Spatial Data Analysis of the Distribution of Regional per Capita GDP in Europe, 1980-1995", Papers in Regional Science, Vol. 82, p. 175-201.

Le Gallo J., Ertur C., Baumont C., 2003, "A Spatial Econometric Analysis of Convergence across European Regions, 1980-1995", in Fingleton B. (ed.), European Regional Growth, p. 99-129, Springer, Berlin.

Lee K., Pesaran M.H., Smith R., 1997, "Growth and Convergence in a MultiCountry Empirical Stochastic Growth Model", Journal of Applied Econometrics, Vol. 12, p. 357-392.

López-Bazo E., Vayá E., Artís M., 2004, "Regional Externalities and Growth: Evidence from European Regions", Journal of Regional Science, Vol. 44, p. 43-73.

López-Bazo E., Vayá E., Mora A., Suriñach J., 1999, "Regional Economic Dynamics and Convergence in the European Union", Annals of Regional Science, Vol. 33, p. 343-370.

Lundberg J., 2003, "The Regional Growth Pattern in Sweden: A Search for Hot Spots", University of Umeå, CERUM Working Paper, $\mathrm{n}^{\circ} 68$, Umeå.

Lundberg J., 2003, "Using Spatial Econometrics to Analyze Local Growth in Sweden", University of Umeå, CERUM Working Paper, no. 67, Umeå.

Magrini S., 2004, "Regional (Di)Convergence", in Henderson V., Thisse J.F. (eds.), Handbook of Urban and Regional Economics, Elsevier Science Publishers, Amsterdam.

Masters W.A., McMillan M.S., 2001, "Climate and Scale in Economic Growth", Journal of Economic Growth, Vol. 6, p. 167-186.

Maurseth B., 2001, "Convergence, Geography and Technology", Structural Change and Economic Dynamics, Vol. 12, p. 247-276.

McArthur J., Sachs J., 2001, "Institutions and Geography: Comment on Acemoglu, Johnson and Robinson (2000)", NBER Working Paper, $\mathrm{n}^{\circ}$ 8114, Cambridge, MA. 
Moreno R., Trehan B., 1997, "Location and the Growth of Nations", Journal of Economic Growth, Vol. 2, p. 399-418.

Murdoch J.C., Sandler T., 2002, "Economic Growth, Civil Wars, and Spatial Spillovers", Journal of Conflict Resolution, Vol. 46, p. 91-110.

Murdoch J., Sandler T., 2004, "Civil Wars and Economic Growth: Spatial Dispersion", American Journal of Political Science, Vol. 48, p. 138-151.

Niebuhr A., 2001, "Convergence and the Effects of Spatial Interaction", Jahrbuch für Regionalwissenschaft (Review of Regional Research), Vol. 21, p. 113-133.

Paci R., Pigliaru F., 2002, "Technological Diffusion, Spatial Spillovers and Regional Convergence in Europe", in Cuadrado-Roura J., Parellada M. (eds.), Regional Convergence in the European Union: Facts, Prospects and Policies, p. 273-292, Springer, Heidelberg and New York.

Ramajo J., Márquez M., Salinas M.d.M., 2003, "Spatial Patterns in EU Regional Growth: New Evidence about the Role of Location on Convergence", Mimeo, Department of Applied Economics, University of Extremadura, Badajoz.

Ramírez M.T., Loboguerrero A.M., 2002, "Spatial Dependence and Economic Growth: Evidence from a Panel of Countries", Banco de la República, Borradores de Economia, ${ }^{\circ}$ 126, Bogotá.

Rey S.J., 2001, "Spatial Empirics for Economic Growth and Convergence", Geographical Analysis, Vol. 33, p. 195-214.

Rey S.J., 2004, "Spatial Dependence in the Evolution of Regional Income Distributions", in Getis A., Mur Lacambra J., Zoller H. (eds.), Spatial Econometrics and Spatial Statistics, Palgrave McMillan, New York.

Rey S.J., Janikas M.V., 2005, "Regional Convergence, Inequality and Space, Journal of Economic Geography, à paraître.

Rey S.J., Montouri B.D., 1999, "U.S. Regional Income Convergence: A Spatial Econometric Perspective", Regional Studies, Vol. 33, p. 143-156.

Roberts M., 2004, "The Growth Performances of the GB Counties: Some New Empirical Evidence for 1977-1993", Regional Studies, Vol. 38, p. 149-165.

Rodrik D., Subramanian A., Trebbi F., 2002, "Institutions Rule: The Primacy of Institutions over Geography and Integration in Economic Development", CID Working Paper, $\mathrm{n}^{\circ}$ 97, Cambridge, MA.

Sachs J.D., Warner A.M., 1997, "Fundamental Sources of Long-Run Growth", American Economic Review, Vol. 87, p. 184-188.

Sachs J., 2000, "Tropical Underdevelopment", CID Working Paper, ${ }^{\circ}$ 57, Cambridge, MA. 
Sandberg K., 2002, "The Dynamics of Economic Growth 1985-2000 in the Chinese Provinces", University of Umeå, Center for Regional Science (CERUM), Interim Report, $n^{\circ}$ IR-02-080, Umeå.

Temple J., 1999, "The New Growth Evidence", Journal of Economic Literature, Vol. 37, p. 112-156.

Tondl G., Vuksic G., 2003, "What Makes Regions in Eastern Europe Catch Up? The Role of Foreign Investment, Human Resources and Geography", Research Institute for European Affairs, IEF Working Paper, ${ }^{\circ}$ 51, Vienna.

Vayá E., López-Bazo E., Moreno R., Suriñach J., 2004, "Growth and Externalities across Economies. An Empirical Analysis using Spatial Econometrics', in Anselin L., Florax R.J.G.M., Rey S. (eds.), Advances in Spatial Econometrics: Methodology, Tools and Applications, p. 433-455, Springer, Berlin.

Verner D., Tebaldi E., 2004, "Convergence, Dynamics and Geography of Economic Growth: The Case of Municipalities in Rio Grande do Norte, Brazil", World Bank Policy Research Paper, $\mathrm{n}^{\circ} 3302$, Washington DC.

Wei S.J., 2000, "Natural Openness and Good Government", NBER Working Paper, $\mathrm{n}^{\circ} 7765$, Cambridge, MA.

Ying L.G., 2000, "Measuring the Spillover Effects: Some Chinese Evidence", Papers in Regional Science, Vol. 79, p. 75-89.

Ying L.G., 2003, "Understanding China's Recent Growth Experience: A Spatial Econometric Perspective", Annals of Regional Science, Vol. 37, p. 613-628.

\section{ESPACE, CONVERGENCE ET CROISSANCE : RÉSULTATS EMPIRIQUES ET MÉTHODES RÉCENTES}

Résumé - Cet article passe en revue la littérature empirique sur la croissance et la convergence soulignant le rôle des interactions spatiales. Une distinction importante est retenue entre localisation absolue et localisation relative. Les approches sur la localisation absolue mobilisent le plus souvent des techniques économétriques non-spatiales et sont fortement liées à la littérature de la croissance économique. En revanche, les approches portant sur la localisation relative tendent à être faiblement reliées à la théorie, mais appliquent des techniques économétriques relativement sophistiquées afin d'inclure les effets spatiaux. La plupart des études de ce dernier type sont régionales par nature, bien qu'il existe un intérêt croissant à étendre l'analyse à un cadre inter-pays. Les études régionales et inter-pays utilisent habituellement les dénommés modèles avec processus spatial. Au lieu de modéliser directement les contraintes 
que sont l'espace et la distance, les modèles avec processus spatial reposent sur une structure spatiale définie d'une façon exogène. Notre revue de la littérature montre que l'utilisation de modèles autorégressifs simples à variable endogène décalée et autocorrélation des erreurs est abondante dans la littérature de l'économétrie spatiale. Nous évaluons la pertinence de tels modèles et identifions des domaines de controverse potentielle. Le faible lien entre la théorie et les modèles opérationnels, la dominance de schémas d'association spatiale "globale" plutôt que "locale", et les restrictions implicites sur l'interaction spatiale induite par un grand nombre des spécifications habituelles des matrices de poids spatial représentent simultanément des voies dans lesquelles des améliorations peuvent être apportées.

\section{ESPACIO, CONVERGENCIA Y CRECIMIENTO : RESULTADOS EMPÍRICOS Y MÉTODOS RECIENTES}

Resumen - Este artículo subraya el papel de las interacciones espaciales revisando los escritos empíricos sobre el crecimiento y la convergencia. Se distinguen fuertemente la localización absoluta y la localización relativa. Las aproximaciones sobre la localización absoluta utilizan en general técnicas econométricas no espaciales y vihinculadas con los escritos sobre el crecimiento económico. En cambio, las aproximaciones acerca de la localización relativa tienden a ser poco relacionadas con la teoria, pero utilizan técnicas econométricas bastante elaboradas para incluir los efectos espaciales. La mayoria de los estudios de este tipo son estudios regionales aunque existe un interés creciente en extender el análisis a un marco inter-paises. Los estudios regionales e inter-paises suelen utilizar los modelos con proceso espacial. En vez de hacer modelos directamente sobre los obstaculos que representan los espacios y la distancia, los modelos con proceso espacial se basan sobre una estructura espacial definida de forma exógena. Nuestra revisión de la literatura muestra que la utilización de modelos autoregresivos sencillos con variable endógena decalada y autocorrelación de los errores son frecuentes en las publicaciones de la econometría espacial. Evaluamos la pertinencia de estos modelos e identificamos los campos de controversa potencial. La poca relación que existe entre la teoría y los modelos que funcionen, la dominación de esquemas de asociación espacial global en vez de local, y las restricciones implícitas sobre la interacción espacial inducida por un gran número de especificaciones habituales de las matrices de peso espacial representan simultaneamente vías en las que puede haber mejoras. 